\title{
Review of Criminal Acts of Selling Forged Documents Through Facebook Social Media
}

\author{
Ni Nyoman Muryatini' \& Ni Wayan Cahya Ayu Pratami ${ }^{2}$ \\ Information System Study Program, Institute of Technology and Business of STIKOM, Bali \\ tiniaryadiputra2016@gmail.com
}

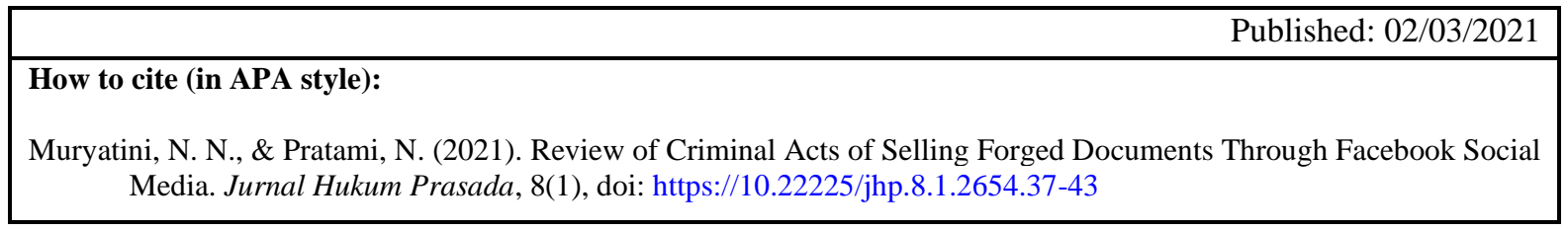

\begin{abstract}
The utilisation of information, media and communication technologies has resulted in the changes in both the behavior of people and human civilization globally. Today information technology has become a double-edged sword, since, in addition to contributing to the improvement of human welfare, progress and civilization, it also constitutes an effective means of committing acts against the law. One of the negative impacts caused and is currently being rife is the emergence of persons who use Facebook to sell forged documents. This study aims to analyse the regulatory regarding the criminal acts of selling forged documents through social media (facebook) in indonesian positive Law. The method used in this study is a normative legal research method. this study was carried out through literature study. The approach used in this study is the statutory approach. In Article 1 paragraph (1) the Criminal Law Code can be viewed that the act of selling forged documents through Facebook cannot be convicted of a crime, because it is not regulated as a prohibited act in the law. However, the offenders can be convicted by referring to articles 263, 264 and 266 of the Criminal Code.
\end{abstract}

Keywords: Criminal Acts; Facebook; Forged Documents

\section{INTRODUCTION}

Globalisation in the world of information makes the State of Indonesia a part of the world's information community. The rapid development and progress of information technology has brought changes to the activities of human life in various aspects which in turn have directly influenced the birth of new forms of legal action.

The utilisation of information, media and communication technology has brought about changes in both the behavior of people and human civilization globally. The development of information and communication technology has also caused the world relations to no longer have boundaries and has led changes in social, economic and cultural spheres which significantly progress so rapidly.

Today the information technology has become a double-edged sword because, in addition to contributing to the improvement of human welfare, progress and civilization, it also serves as an effective means for the emergence of acts against the law.

One of the negative impacts arising from technological developments that are currently rife is the emergence of individuals who utilise Facebook to sell forged documents. Various kinds of forged documents are offered, such as Identity Card (KTP), Family Card (KK), Birth Certificate, Marriage Certificate, Certificates (started from elementary to university level), Academic Transcript, Vehicle Registration Certificate (STNK), Certificate of Ownership of Motor Vehicles $(B P K B)$, Statement of Police Records (SKCK), Teacher Certificates, and Land Certificates. 
Desi Wulandari argued, "The act of counterfeiting is one of the deviant behavior and is against the law that is detrimental to society, and currently has developed rapidly both the modus operandi and the culprit. The perpetrators of counterfeiting today are not only from ordinary people but also from many elements in government".

According to Prof. Van Bemmelen and Prof. Van Hattum, material forgery is almost always done by people with a clear intention, namely to utilise or to make others use the forged object as an object that is not falsified, whereas in intellectual counterfeiting, although this kind of forgery has often taken place, it is also accompanied by unjustifiable intentions. However, the striking characteristic of intellectual counterfeiting is the existence of a lie which is explained or revealed by a person in a writing (Dianti, 2017). Based on Article 1 paragraph (3) of the 1945 Constitution, the State of Indonesia is a State of Law, and as such, any act that violates the provisions of the law certainly has its sanctions.

There are countless cases of document forgery that have been legally processed, but they were only limited to those who use the services of forged documents selling. It is hardly heard that the legal process touches the parties who make and then trade the forged documents. Now the persons who engage themselves in trading the forged documents have commencing to use a social medium, called Facebook, as a marketing place that results in more people being able to access the information.

Although it is virtual in nature, activities carried out through electronic system-based media can be categorized as real legal actions. Juridically, activities in cyberspace cannot be approached with conventional legal measures and qualifications because if this method is pursued there will be too many difficulties and things that escape law enforcement. An activity on cyberspace is included as a virtual activity that has a very real impact even though the evidence is electronic. Thus the subject of the culprit shall also qualify as a person who has committed a real legal act.

In this regard, there is a need for taking notice at the aspects of security and legal certainty in the utilisation of information, media and communication technology whose purpose is to foster the optimal development. In an effort to overcome the problems of security in the operation of electronic systems, the legal approach is absolute because without the legal certainty, the problem of utilising the information technology remains nonoptimal.

Not only is electronic information has not yet been accommodated in the Indonesian procedural law system comprehensively, but it has also turned out to be very vulnerable to be changed, tapped, falsified and sent to various parts of the world in just seconds, and thus the resulting impact can be so complex and complicated. Therefore, proof is a very important thing to undertake. Therefore, this study aims to analyse the regulatory regarding the criminal acts of selling forged documents through social media (facebook) in indonesian positive Law.

\section{METHODS}

The method used in this study is a normative legal research method aimed at finding out and formulating the legal argumentation through analyses of the subject matter. The collection legal material for this study was carried out through literature study. The legal material used in this study are primary, secondary, and tertiary legal materials. The approach used in this study is the statutory approach, that is, by examining the applicable legal rules related to the criminal acts of forged documents sales through social media, the Facebook.

\section{RESULT AND DISCUSSION Overview of Criminal Acts}

Criminal acts are the acts that are prohibited by a prohibiting legal rule accompanied by the threat of sanctions in the form of certain penalties for anyone who commits violations on it (Moeljanto, 2002). A legal action represents every act or action of a legal subject that has legal consequences. 
Criminal acts are the acts that are contrary to the order provided by the law. Strictly speaking, the perpetrators of these criminal acts are detrimental to the community, in the sense of being contrary to or hindering the process of the implementation of good and fair social relations (Poernomo, 1994).

Formal criminal acts are criminal acts that are formulated in such a way that it gives the meaning that the essence of a prohibited formulation is to commit certain actions. The formulation of formal criminal acts overrules attention or does not require the emergence of a certain consequence of the act as a condition for the completion of the criminal act, but solely on the act.

On the contrary, in the formulation of material criminal acts, the core of the prohibition lies in causing prohibited consequences, therefore those who cause the prohibited consequences are responsible and criminalized. A matter concerning the forms of actions that cause illicit results is unimportant.

A criminal act, from an objective perspective, is an action (acting or negligence) that is contrary to positive law which results in a law which is prohibited by threat of punishment.

Conversely, from a subjective point of view a criminal offence higlights that any unintended consequence of the comitted act can be weighted against the perpetrators of it (Van Apeldoorn, 2001). elements:

Fundamental division in reviewing the formulation of offence only consists of two basic

a. The objective part referring to offense consists of actions and consequences, which are events that are contrary to positive law as an element that is against the law which can be threatened with criminal penalties.

b. The subjective part which is the element of fault rather than offense.

According to Van Apeldoorn (2001), the element of offence consists of an objective element in the form of a behavior that is contrary to the law and a subjective element in the form of an unlawful perpetrator who is capable of being liable or can be incriminated with the violated law.

Forgery is the process of making, adapting, or imitating objects, statistics or documents with a view to deception. Criminal acts similar to fraud are the ones that are committed to deceive others, including through the utilisation of objects obtained through an act of forgery.

Forgery is a type of violation of truth and belief, with the aim of obtaining benefits for oneself or others. A regular association of life in an advanced society cannot take place without the guarantee of the authenticity of some documentary evidence and other documents. Therefore, a kind of forgery can be a threat to the survival of the community concerned.

A criminal act of forgery according to Prasetyo (2011) is a crime in which it contains an untruthful or false system of a thing (object) which from the outside of the thing (object) in question looks as if something is genuine and true in nature while actually contradicting the original form; that is what is called a forgery in the form of criminal acts and violation.

\section{Regulatory regarding the Criminal Acts of Selling Forged Documents through Social Media (Facebook) in Indonesian Positive Law}

Based on article 3 of Law Number 11 of 2008 concerning Information and Electronic Transactions (ITE), the use of information technology and electronic transactions is carried out based on the following principles:

1. The principle of legal certainty, which means a legal basis for the use of information technology and electronic transactions as well as everything supporting its implementation that shall obtain a legal recognition inside and outside the court;

2. The benefit principle, which means that the principle for the utilization of information technology and electronic transactions is sought to support the process of information exchanging so it can improve the welfare of the community; 
3. The precautionary principle, which means that the foundation for the party concerned shall pay attention to all aspects that have the potential to cause harm in the use of information technology and electronic transactions, both for himself and for other parties;

4. The principle of good faith, which means that the principle used by the parties in carrying out electronic transactions is not intended to intentionally and without rights or against the law resulting in losses to other parties without the knowledge of the other party;

5. The principle of freedom of choice of technology, which means that the principle of utilising the information technology and electronic transactions is not restricted to the use of a certain technology so that they can follow developments in the future.

The definition of a document according to the big Indonesian dictionary is: 1 . Written or printed letters that can be used as proof of information (such as birth certificates, marriage certificates, letters of consent; 2. Printed materials or manuscripts sent by post; 3 . Voice recordings, pictures in the film, and so on, which can be used as evidence of information.

The concept of electronic documents, in Act Number 19 of 2016 concerning Amendments to Act Number 11 of 2008 concerning Information and Electronic Transactions, is prescribed in the Article 1 paragraph (4) which specifies, "Electronic documents are any electronic information that is made, passed on, transmitted, received or stored in analog, digital, electromagnetic, optical or the like, which can be seen, displayed and/or listened to through a computer or electronic system, including but not limited to writing, sound, images, maps, designs, photographs or the like, letters, signs, numbers, access codes, symbols or perforations that have significance or meaning or can be understood by people who are able to understand."

In Article 1 paragraph (1) of the ITE Law it specifies, "Electronic information is one or a collection of electronic data, including but not limited to text, sound, images, maps, designs, photographs, electronic data interchange (EDI), electronic mail, telegram, telex, telecopy or the like, letters, signs, numbers, access codes, symbols, or processed perforations that have meaning or can be understood by people who are able to understand them."

Based on article 5 paragraph (1) of Law Number 11 of 2008 concerning Information and Electronic Transactions it is specified that, "Electronic information and/or electronic documents and/or printouts constitute valid legal evidence." In paragraph (2) it then specifies, "Information electronic and/or electronic documents and/or printouts as referred to in paragraph (1) are extensions of valid evidence in accordance with the applicable Procedure Law in Indonesia."

The act of trading forged documents through Facebook can be categorised as a real legal act or act and is a valid proof that the offender provides electronic information by selling various forged documents.

The Indonesian ITE law does not regulate the prohibition of providing information through selling something that is prohibited by law, specifically the trading of forged documents. This shows that the Indonesian ITE Law has not regulated in full the criminal acts that might occur in the cyber world. In turn, of course this can bring about an impact on the perpetrators of criminal acts of selling forged documents through Facebook to be never be deterred of continuing to commit these actions since there are no laws that stipulate a ban on them.

In conjunction with the absence of legal rules prohibiting the criminal acts of forged documents trade on social media, in article 1 paragraph (1) of Indonesian Criminal Code it is specified, "An act shall not be convicted, except it is executed based on the strength of existing criminal law provisions." If it viewed from the Indonesian ITE Law which is the law specifically regulating the provisions on Electronic Information and Transactions in Indonesia, the act of selling forged documents through Facebook cannot be convicted, since it is not regulated as a a prohibited act in the law. 
If viewed from the Criminal Code, a counterfeiting is a form of crime regulated in Chapter XII of Book II of the Criminal Code, wherein the book states that the forgery deemed a criminal act is only which is made in the form of writing.

The criminal acts that have often taken place were the ones relating to the article 263 of the Criminal Code concerning making forged letters or letter fabrication, the article 264 of the Criminal Code concerning falsifying authentic deeds, and the article 266 of the Criminal Code concerning ordering to insert false information into an authentic deed.

Article 263 of the Criminal Code reads as follows:

1) Any person who forges or falsifies a writing from which \& title, a contract or a release from debt may arise, or which is intended to serve as evidence of a fact, with intent to use or to cause others to use it as genuine and unfalsified, shall, if from said use may result an injury, being guilty of forgery of writing, be punished by a maximum imprisonment of six years;

2) By the same punishment shall be punished the person who with deliberate intent makes use of the false or falsified writing as if it were genuine and unfalsified, if from said use may result an injury.

The falsification of the letter intened in article 263 of the Criminal Code occurs in two forms of criminal acts, each of which is formulated in paragraph (1) and paragraph (2). Based on the element of the actions, the falsification of the letter in paragraph (1) the one is done by making a fake letter and falsifying the letter, while the falsification of the letter in paragraph (2) is the one done using a fake letter or a forged letter.

Although the two forms of crime are interrelated, each one stands alone on a different tempos and locus of criminal acts and can be executed out by different makers. If the formulation of paragraph (1) is made details, the following elements are be obtained (Chazawi \& Ferdian, 2016):

Objective elements:

a. To make to be forged;

b. To falsify;

c. Any document that can give rise to rights;

d. Any document that can cause an engagement;

e. Any document that can lead to a debt relief;

f. Any document that is intended as evidence of a matter.

Subjective elements:

An offence with the intention to use or order someone else to use a document so that it appears as if the contents are authentic and not falsified:

In the formulation of the act of forgery in paragraph (1) there are two kinds of the acts of falsification, namely making a document false and falsifying a document in conjunction with a letter as its object. The first act is usually called the act of making a fake letter. The essence of making a letter into a fake one is to make a letter that did not exist before. It is a letter whose contents or in certain parts do not correspond to original or contradict the truth in original or letters that result from the act of making a fake letter. This is called a fake letter or a letter that is not original.

Article 264 of the Criminal Code reads as follows:

1) Any person guilty of forgery of writing shall be punished by a maximum imprisonment of eight years, if it is committed:

a. in authentic deeds;

b. in debentures or certificates of debts of a state or Part thereof or of a public institution;

c. in shares or debentures or share certificates or debt certificates of an association, foundation, partnership or company;

d. in counterfoils, dividend or interest evidences belonging to one of the documents described under both or the foregoing numbers, or in evidence issued in substitution for these documents; 
e. in credit or commercial papers intended for circulation

2) By the same punishment shall be punished any person who with deliberate intent makes use of a false or falsified writing mentioned in the first paragraph as if it were genuine and unfalsified, if from said use an injury may result.

Article 266 reads as follows:

1) Any person who causes to insert a false statement in an authentic deed concerning a fact, the truth of which the deed must give proof, with intent to use or to cause others to use said deed as if his statement were in accordance with the truth, shall, if from said use an injury may result, be punished by a maximum imprisonment of seven years.;

2) By the same punishment shall be punished any person who with deliberate intent makes use of the deed as if the contents were in accordance with the truth, if from said use an injury may result.

Perpetrators of criminal acts of selling forged documents through Facebook can be convicted by referring to the Criminal Code as stipulated in articles 263, 264 and 266 of the Criminal Code.

\section{CONCLUSION}

The Indonesian Law on and Electronic Information and Transactions (ITE) has not yet regulated provisions regarding the prohibition on the act of providing information to sell something that is prohibited by the law, specifically the act of selling forged documents. This shows that the Law on the ITE has not thoroughly regulated the criminal offences that might occur in the cyber world. Of course this can bring about an impact on criminal offenders who trade forged documents through Facebook, in that, they will never feel deterrent to continue to carry out these actions because there are no laws governing the provisions of prohibitions on them.

In Article 1 paragraph (1) the Criminal Law Code specifies, "No act shall be punished unless by virtue of a prior statutory penal provision" If it is viewed from the Indonesian ITE Law, which is a law that contains legal provisions that specifically regulate Electronic Information and Transactions in Indonesia, the act of selling forged documents through Facebook cannot be convicted of a crime, because it is not regulated as a prohibited act in the law. However, the offenders can be convicted by referring to articles 263, 264 and 266 of the Criminal Code.

It is expected that the Indonesian government needs necessarily to immediately revise the Law on Information, Technology and Electronics (ITE) by adding to the law the prohibiting provisions of criminal offences that may result in the world of information exchange and electronic transactions, since the legal rules regarding these aspec have not yet been regulated completely and comprehensively. This is especially true for the crime of selling forged documents through social media, including Facebook.

\section{REFERENCES}

Chazawi, A., \& Ferdian, A. (2016). Tindak Pidana Pemalsuan (2nd ed.). Jakarta: PT. Raja Grafindo Persada.

Dianti, V. P. (2017). Tindak Pidana Pemalsuan Surat: Analisis Terhadap Putusan Hakim Dalam Perkara Nomor 38/Pid.B/2016/PN.SIw di Pengadilan Negeri Slawi. Universitas Negeri Semarang.

Moeljanto. (2002). Asas-asas Hukum Pidana. Jakarta: Rineka Cipta.

Poernomo, B. (1994). Asas-asas Hukum Pidana. Jakarta: Ghalia Indonesia.

Prasetyo, T. (2011). Hukum Pidana. Jakarta: Raja Grafindo.

Van Apeldoorn, L. J. (2001). Pengantar Ilmu Hukum. Jakarta: Pradnya Paramita.

Kitab Undang-Undang Hukum Pidana, www.hukumonline.com, accessed on April 29, 2019.

Undang-Undang Nomor 11 Tahun 2008 Tentang Informasi dan Transaksi Elektronik, www.hukumonline.com, accessed on April 29, 2019.

Undang-Undang Nomor 19 Tahun 2016 Tentang Perubahan Atas Undang - Undang Nomor 11 
Tahun 2008 Tentang Informasi dan Transaksi Elektronik, www.hukumonline.com, accessed on April 29, 2019. 